\title{
Article
}

\section{Impact of integrin-matrix matching and inhibition of apoptosis on the survival of purified human beta-cells in vitro}

\author{
F. Ris ${ }^{1,2}$, E. Hammar ${ }^{1}$, D. Bosco ${ }^{1}$, C. Pilloud ${ }^{1}$, K. Maedler ${ }^{3}$, M. Y. Donath ${ }^{3}$, J. Oberholzer ${ }^{2}$, E. Zeender ${ }^{1,2}$, \\ P. Morel $^{2}$, D. Rouiller ${ }^{1}$, P. A. Halban ${ }^{1}$ \\ ${ }^{1}$ Louis-Jeantet Research Laboratories, University of Geneva Medical Center, ${ }^{2}$ Division of Surgical Research, \\ Department of Surgery, University Hospital, Geneva, Switzerland \\ ${ }^{3}$ Division of Endocrinology and Diabetes, University Hospital, Zurich, Switzerland
}

\begin{abstract}
Aims/hypothesis. Human islet cells survive poorly in culture and are overgrown by non-endocrine cells. The aims of this study were to sort human beta cells and to develop approaches for their improved survival in culture.

Methods. Human islets were infected with recombinant adenovirus expressing green fluorescent protein (GFP) under the control of the rat insulin promoter such that only beta cells expressed GFP. GFP-positive beta cells were sorted by flow cytometry, and expression of select integrins evaluated by RT-PCR. Beta cells were cultured on different extracellular matrices for up to 15 days. Apoptosis was measured by annexin $\mathrm{V}$ binding and ELISA. Insulin secretion was measured by ELISA.

Results. Sorted beta cells survived less well in culture than unsorted islet cells. This did not appear to be due to adenoviral infection and/or GFP expression. Puri-
\end{abstract}

fied beta cells expressed the integrins $\alpha 3, \alpha 5, \alpha 6, \alpha \mathrm{V}$, $\beta 1$, but not $\beta 4$. Of the various matrices tested, sorted beta cells attached and spread best on a lawn of lysed human bladder carcinoma cells (5637 cells). However, survival remained poor. Cell death was decreased but not prevented by continued presence of $10 \mathrm{mmol} / \mathrm{l}$ nicotinamide and apoptosis decreased by $24 \mathrm{~h}$ incubation with $20 \mu \mathrm{mol} / \mathrm{l} \mathrm{Z}$-VAD. Insulin secretion was maintained over 6 days following treatment with both agents.

Conclusions/interpretation. Purification of human beta cells induces marked apoptosis limiting their function and survival in vitro. This was improved by matching the extracellular matrix to the specific expression of integrins and by addition of nicotinamide and Z-VAD. [Diabetologia (2002) 45:841-850]

Keywords Integrins, human beta cells, apoptosis, extracellular matrix, insulin secretion, GFP, islet.
With improved methods for islet transplantation, it is clear that one of the limiting factors for the widespread use of this approach for the treatment of diabe-

Received: 20 December 2001 / Revised: 12 February

2002Published online: 8 May 2002

C Springer-Verlag 2002

Corresponding author: Dr. P. A. Halban, Louis-Jeantet Research Laboratories, University of Geneva Medical Center, 1 rue Michel-Servet, 1211 Geneva 4, Switzerland, e-mail: philippe.halban@medecine.unige.ch

Abbreviations: $\beta$; -Gal, Beta-galactosidase; CMV, cytomegalovirus; ECM, extracellular matrix; GFP, green fluorescent protein; OD, optical density; RIP, rat insulin promoter; RT, reverse transcription; UW, University of Wisconsin tes is the shortage of human tissue $[1,2,3]$. Some other approaches will depend on the ability to maintain and propagate human islet beta cells in culture, and these include current attempts to conditionally transform such cells $[4,5]$. The success of attempts to derive beta cells/islets from stem cells, whether adult [6] or embryonal [7, 8, 9], will also depend ultimately on the survival of the fully differentiated endocrine/ islet cells in culture. However, human islet cells do not seem to be as hardy in culture as their rodent counterparts and even the purest preparations of human islets contain non-endocrine (fibroblastoid) cells that proliferate quickly in culture. This is probably important in islet transplantation as well, given that human islets are invariably maintained in culture before 
their transplantation, even if only for short periods. We described recently a method to purify human adult beta cells, using an adenovirus expressing the green fluorescent protein under control of the rat insulin promoter with subsequent fluorescence activated cell sorting [10]. Such purified beta cells might be of value as starting material in the attempt to develop lines of human beta cells by conditional transformation. Absence of contaminating non-beta-cells would also allow for detailed characterization of beta-cell-specific molecules possibly implicated in long-term maintenance of differentiated function, a prerequisite for successful transplantation or cell replacement therapy of diabetes. However, this will depend upon the ability of these cells to survive in culture. Collagenase digestion of the pancreas to isolate islets [11], and their subsequent dispersion into a single cell preparation [10] involves disruption of cell-cell and cell-extracellular matrix contacts. Such disengagement of cell adhesion molecules and of integrin receptors for elements of the matrix is known to result in perturbation of differentiated function of rodent beta cells [12] and to prejudice cell survival [13], notably by inducing apoptosis and necrosis $[14,15,16]$, as well as a loss of function [17]. Reestablishment of appropriate cell to matrix contacts reduces apoptotic signals [18].

This study aimed to improve the survival of adult human beta cells in culture. Modifications to standard culture conditions were made on the basis of an improved match between integrins expressed by such cells and the extracellular matrix. Moreover, addition of select factors known to limit apoptosis, or promote cell differentiation, was evaluated for improving survival of purified beta cells in culture.

\section{Materials and methods}

Isolation of human islets. Pancreases were harvested from different multi-organ cadaveric donors (20-65 years of age) after hypothermic perfusion through the abdominal aorta and the inferior mesenteric vein, and stored in University of Wisconsin solution (UW) (DuPont Pharma, Bad Homburg, Germany) at $4^{\circ} \mathrm{C}$ in a temperature self-regulated organ transport system (HUG-box; Safetherm, Geneva, Switzerland). Mean cold ischaemia time before the isolation procedure was $6 \mathrm{~h}$ (range 4-8 h).

Islets were isolated by a modified semi-automated method as described in detail previously [1, 19]. Briefly, the pancreas was cleaned from the surrounding fat and fibrotic tissues. It was then canulated and injected with $250 \mathrm{ml}$ warm $\left(30^{\circ} \mathrm{C}\right)$ Hank's solution containing $2 \mathrm{mg} / \mathrm{ml}$ Liberase (Liberase-HI, Roche, Basel, Switzerland). The distended pancreas was placed in the digestion chamber, which was warmed at $37^{\circ} \mathrm{C}$, using an electronic controlled heating system. The chamber was shaken and gently agitated during the digestion. Samples were taken regularly and the digestion was stopped according to the appearance of free islets in samples, the amount of digested tissue and on the macroscopic digestion status of the organ. The digestion was stopped using cold $\left(4^{\circ} \mathrm{C}\right)$ Hanks' solution containing 5\% newborn calf serum (Seromed, Berlin, Ger- many) injected into the circulating system. Tissue was collected and centrifuged for $1 \mathrm{~min}$ at $256 \times \mathrm{g}$. The pellet was resuspended in UW solution at $4^{\circ} \mathrm{C}$ and the islets were purified by a discontinuous Euro-Ficoll gradient (Sigma, St-Louis, Mo., USA) on 1.108 (bottom layer), 1.096, 1.037, 1.006 (top layer) densities on a cell separator (Cobe 2991, Cobe, Lakewood, Co., USA). Islets were cultured in non-adherent culture flasks (Gibco, Paisley, Scotland) in Connaught Medical Research Laboratory culture medium (CMRL 1066, Sigma) supplemented with $10 \%$ fetal calf serum (Gibco), $1 \%$ glutamine (Merck, Darmstadt, Germany), 1\% HEPES, penicillin and streptomycin (Sigma) (hereafter referred as CMRL) and incubated at $24^{\circ} \mathrm{C}$ for $24 \mathrm{~h}$.

Islets from 40 isolations were used for the various experiments described. The mean age of the patients was 47.2 years (range 22-66), with $33 \%$ women $(n=13)$ and $67 \%$ men $(n=27)$. Islet purity was baded on staining with dithizone. The purity was $80.1 \pm 2.5 \%$ (mean $\pm \mathrm{SE}, n=40$ ). The range of purity was $40-95 \%$ with only six preparations with a purity of less than $70 \%$.

Dissociation of islets and infection of islets cells with recombinant adenovirus. After 24-h incubation, islets were washed twice with phosphate-buffered saline without $\mathrm{Mg}^{2+} / \mathrm{Ca}^{2+}$ $\left(\mathrm{PBS}^{-}\right)$and resuspended in $2 \mathrm{ml}$ of enzyme-free "dissociation buffer" (C-5789, Sigma), with frequent pipetting through a $1 \mathrm{ml}$ plastic tip. The dispersed cells and small remaining clusters obtained at this stage, were pooled, washed once with CMRL medium and (when indicated) resuspended in this same medium supplemented with $10 \mathrm{mmol} / \mathrm{l}$ nicotinamide at a concentration of $10^{6}$ cells $/ \mathrm{ml}$.

Recombinant adenovirus expressing green fluorescent protein (GFP) under the control of the rat insulin promotor (RIP) was prepared as described in detail previously. Virus titre was defined and used as discussed earlier [10]. The cell preparation was then incubated for $90 \mathrm{~min}$ at $37^{\circ} \mathrm{C}$ with the virus (Ad-RIPGFP). After washing, the infected cells were cultured in nonadherent plastic dishes for $48 \mathrm{~h}$ to $72 \mathrm{~h}$. GFP expression was assessed by inverted fluorescence microscopy. Dissociated islets were also infected by CMV- $\beta \mathrm{Gal}$ and CMV-GFP adenoviruses, to assess whether GFP or adenoviral infection in itself was deleterious for human beta cells. After $96 \mathrm{~h}$ of incubation, these dissociated islet cells were fixed in $4 \%$ paraformaldehyde for TUNEL/insulin immunostaining or lysed for quantification of apoptosis by ELISA as described below.

Fluorescence-activated cell sorting (FACS) of human beta cells. GFP-expressing cells were harvested and treated with a solution of $0.025 \%$ trypsin (Gibco) in $\mathrm{PBS}^{-}$containing $0.3 \mathrm{mmol} / \mathrm{l} \mathrm{EDTA}$ for $6.5 \mathrm{~min}$ at $37^{\circ} \mathrm{C}$ (with occasional pipetting through a $1 \mathrm{ml}$ plastic tip) to obtain a suspension of dissociated cells. The digestion was stopped by addition of CMRL medium complemented with $10 \mathrm{mmol} / \mathrm{l}$ nicotinamide. After washing once with the same medium, cells were resuspended in $1 \mathrm{ml}$ of the medium and passed 30 times through a $1 \mathrm{ml}$ plastic tip (blue plastic type "F2" from Semadeni Ostermundigen, Switzerland). Remaining debris and large aggregates were discarded by sedimentation and the cell concentration was adjusted to 0.5 to $1 \times 10^{6}$ cells $/ \mathrm{ml}$. Cells were kept at $4^{\circ} \mathrm{C}$ until cell sorting. Cells were sorted using a FACStar-Plus (Beckton Dickinson) with an argon laser beam tuned to $488 \mathrm{~nm}$ at $50 \mathrm{~mW}$ output with a $530 \pm 30 \mathrm{~nm}$ emission filter as described previously [10]. In biparametric plots, forward scatter (FSC) related to cell size. Presorting gates (side scatter (SSC) vs FSC) were set to exclude non-cellular debris and groups of more than one cell. Non-infected cells were used as a control and to set the sorting parameters such that the GFP quadrant in 
the biparametric plot (log fluorescence versus FSC) included less than $0.3 \%$ of control cells. Cells were sorted at a rate of 1500-2500 events per s using normal recovery mode. Cells were collected in $1.5 \mathrm{ml}$ plastic microtubes carrying $1 \mathrm{ml}$ of CMRL medium complemented with $10 \mathrm{mmol} / \mathrm{l}$ nicotinamide. After sorting, the cells were centrifuged at $2000 \mathrm{rpm}$ for $10 \mathrm{~min}$ and resuspended either for culture (using the appropriate medium and cell concentration, see below) or in $300 \mu \mathrm{l}$ of RNeasy RLT lysis buffer (Qiagen, Basel, Switzerland) complemented with $10 \mu \mathrm{l} / \mathrm{ml} \beta$-mercaptoethanol/ for RNA extraction (see below).

Preparation of pancreatic fibroblasts. In order to prepare a stock of pancreatic fibroblastoid cells (that normally overgrow human islets in culture), human islets were placed in culture in $75 \mathrm{~cm}^{2}$ surface area flasks using CMRL medium with $10 \%$ FCS. The medium was changed after a week and any floating islets/cells discarded. Once the cultures became confluent, they were passaged (trypsinized and diluted before reculturing) using standard techniques. There was progressive loss of insulin secretion to the culture medium with time, in keeping with the poor long-term survival of beta cells in culture and their overgrowth with fibroblastoid cells. After 3 weeks in culture, it was confirmed by immunofluorescence and infection with Ad-RIPGFP that there were no longer any detectable insulin-containing beta cells. On this basis, the rapid rate of proliferation and the morphological aspect of the cells, this preparation was considered to be composed of fibroblastoid cells and is referred to as pancreatic fibroblasts for the purposes of this study.

Culture conditions. Sorted beta cells were washed once with culture medium with nicotinamide $10 \mathrm{mmol} / \mathrm{l}$ (when indicated) and gentamycin $100 \mu \mathrm{g} / \mathrm{ml}$, and resuspended in this medium at a concentration of approximately $0.4 \times 10^{6}$ cells/ $\mathrm{ml}$. The cell suspension was plated in non-adherent Petri dishes in $50 \mu \mathrm{l}$ droplets, and incubated for $24 \mathrm{~h}$ at $37^{\circ} \mathrm{C}$. For assessment of different culture media, cells were washed once and resuspended in the appropriate medium, containing $10 \%$ FCS, $1 \%$ glutamine (Merck, Darmstadt, Germany), 1\% HEPES, penicillin and streptomycin (Sigma). When indicated, cells were seeded in 96-well plates pre-coated with specific ligands as noted in Results. The caspase inhibitor Z-VAD (FK009, Enzyme System Products, Livermore, Canada) was used at $20 \mu \mathrm{mol} / 1$ and was added to the cells for $24 \mathrm{~h}$ after cell sorting.

Extracellular matrices. Gelatine (2\% solution, from bovine skin, Sigma), bovine fibronectin $(5 \mu \mathrm{g} / \mathrm{ml}$ from Sigma) and human vitronectin $(0.1 \mu \mathrm{g} / \mathrm{ml}$ from Sigma) were coated on Petri dishes and incubated at least $30 \mathrm{~min}$, then washed twice with sterile water and dried under the hood [20]. Matrix from medium conditioned by $804 \mathrm{G}$ cells (the generous gift of Desmos, Calif., USA) was prepared and used as described previously [12]. For lawns of lysed cells, 5637 (human bladder carcinoma) cells were grown to confluency and then lysed by exposure for $3.5 \mathrm{~min}$ to sterile $\mathrm{H}_{2} \mathrm{O}$ followed by two washes with $\mathrm{PBS}^{-}$. Petri dishes were stored at $4^{\circ} \mathrm{C}$ after air drying. Shortly before use, the dishes were washed once again and dried under the hood.

Evaluation of apoptosis. Annexin V is a $\mathrm{Ca}^{++}$dependant phospholipid-binding protein with a high affinity for phosphatidylserine (PS) [21, 22]. In an early apoptotic state, PS is known to translocate from the inner to the outer leaflet of the plasma membrane. Thus annexin V tagged with Alexa 568 (Molecular Probes, Leiden, Netherlands) can be used to identify apoptotic cells as from the earliest stage of programmed cell death [22].
To this end, beta cells were washed once with cold PBS and resuspended at a concentration of $10^{6}$ cells $/ \mathrm{ml}$ in annexin binding buffer $(\mathrm{ABB})(140 \mathrm{mmol} / \mathrm{l} \mathrm{NaCl}, 10 \mathrm{mmol} / \mathrm{l}$ Hepes, $2.5 \mathrm{mmol} / \mathrm{l} \mathrm{CaCl} 2, \mathrm{pH} 7.4) .5 \mu \mathrm{l}$ of annexin conjugate was added to each $100 \mu \mathrm{l}$ of cell suspension. After 15 min of incubation at room temperature, the cell suspension was diluted fivefold and kept at $4^{\circ} \mathrm{C}$ until the labelled cells were analysed by fluorescence microscopy.

Later-phase apoptotic events were quantified using Cell Death Detection Elisa (Roche Biochemicals, Mannheim, Germany) for determination of cytoplasmic histone-associatedDNA-fragments (mono- and oligonucleosomes) in the cell lysate for apoptosis or in the supernatant for necrosis. This method allows for comparison of two cell preparations but does not provide any indication of the absolute incidence of apoptosis in either, and data for test conditions are presented relative to control subjects.

DNA fragmentation was assessed visually by the terminal deoxynucleotidyl transferase-mediated dUTP nick-end labelling technique (TUNEL) performed according to the manufacturer's instructions (In situ cell death detection kit, AP from Boehringer Mannheim, Germany). For TUNEL combined with immunostaining for insulin, dissociated cells were seeded as $50 \mu \mathrm{l}$ droplets $(20,000$ cells/droplet) in the centre of $3 \mathrm{~cm}$ diameter Petri dishes carrying a lawn of lysed 5637 cells. Cells were fixed with $4 \%$ paraformaldehyde (20 min, room temp) followed by permeabilisation with $0.5 \%$ Triton X-100 (4 min, room temp). For insulin immunostaining, cells were incubated at $37^{\circ} \mathrm{C}$ for 30 min with guinea pig anti-insulin antiserum (1:50, Dako, Carpinteria, Calif., USA) followed by $30 \mathrm{~min}$. incubation with fluorescein-conjugated rabbit anti-guinea pig antiserum (1:20, Dako).

RNA extraction, reverse transcription and semi-quantitative $P C R$. RNA extraction was performed on purified beta cells, islets and human fibroblastoid cells grown in culture from human islets. RNA extraction was performed with the RNeasy mini kit (Qiagen, Basel, Switzerland) according to the standard protocol, using the lysis buffer (RLT buffer) for disruption and the QIA shredder column for homogenisation of the sample. RNA levels were assessed by measuring the O.D. $\left(A^{260}=\right.$ $40 \mu \mathrm{g} / \mathrm{ml}$ ). RT was performed on RNA using the Superscript II RNase $\mathrm{H}^{-}$Reverse transcriptase (Life technologies, Gibco). Equal amounts of RNA were used from each cell preparation. The quality of cDNA was controlled with a PCR for actin with the following primers: Forward: 5' cccacaacgtgcccatttat $3^{\prime}$, Reverse: $5^{\prime}$ ttggcatacaggtccttcct $3^{\prime}$, giving a fragment of 411 basepairs in length.

Specific primers were designed with a high theoretic specificity for human integrin, according to the search in the Blast NCBI nucleotide and protein databases and verification in the Amplify 1.2 programme. The specific primers were:

$\alpha 3$ forward: 5' agatgcgggcagccttcg 3', reverse: 5' gttttcatgccagactcacc $3^{\prime}$; $\alpha 5$ forward: 5' agccaaagtctgcagttgcattt $3^{\prime}$, reverse: $5^{\prime}$ atgaagagggtatgtgtaaacaag $3^{\prime} ; \alpha 6$ forward: $5^{\prime}$ tgagcacatattcgatgag $3^{\prime}$, reverse: $5^{\prime}$ cccacacgctgttttctgg $3^{\prime} ; \alpha \mathrm{V}$ forward: $5^{\prime}$ atgaaaatctggtagatcctat $3^{\prime}$, reverse: $5^{\prime}$ ttcctgtaacatcatgctattg 3'; $\beta 1$ forward: 5' gactattgaaatcaagcttat $3^{\prime}$, reverse: $5^{\prime}$ gttctttatctaaggettg 3'; $\beta 4$ forward: $5^{\prime}$ accaactactcctatagctacta $3^{\prime}$, reverse: $5^{\prime}$ agacttcgtgtgcggacagt $3^{\prime}$.

For each set of primers, the signal from 5 different numbers of PCR cycles was quantified and compared using a cycle number within the linear (non-saturating) range for all cell preparations. Semi-quantitative RT PCR were performed from 23 to 38 or 26 to 41 PCR cycles, taking one sample every three cycles. A representative experiment is shown for $\beta 1$ in Fig. 2. 
Static insulin secretion. Sorted beta cells were cultured in suspension for $24 \mathrm{~h}$ and either studied directly for insulin secretion or plated on lysed 5637 cells and cultured in CMRL containing $10 \mathrm{mmol} / \mathrm{l}$ nicotinamide for a further 6 days. Before the test incubation, the cells were washed with Krebs-RingerHepes buffer (KRB), $2.8 \mathrm{mmol} / \mathrm{l}$ glucose, $0.1 \%$ BSA. After 30 min of preincubation in KRB at this same glucose concentration, beta cells were incubated for $1 \mathrm{~h}$ at low glucose ( $2.8 \mathrm{mmol} / \mathrm{l})$ followed by $1 \mathrm{~h}$ at high glucose $(16.7 \mathrm{mmol} / \mathrm{l})$, with or without the addition of $0.1 \mathrm{mmol} / \mathrm{l} \mathrm{IBMX}$ and $5 \mu \mathrm{mol} / \mathrm{l}$ forskolin. Cellular insulin was extracted in acid ethanol. Samples were analysed by the Ultrasensitive Insulin ELISA from Mercodia (Uppsala, Sweden) following dilution to allow for measurement in the linear range of the assay.

Data analysis. Data are presented as means \pm SEM and statistical significance was tested by Student's unpaired t-test where applicable. A $p$ value of less than 0.05 was considered to be statistically significant.

\section{Results}

Effect of culture medium on morphological appearance and survival of purified beta cells in culture. Following infection by the adenovirus expressing GFP under the control of the rat insulin promoter (AdenoRIP-GFP), fluorescent beta cells were sorted by FACS. The beta cells were allowed to recover overnight in non-adherent plastic dishes and then seeded on adherent plastic dishes using the following culture media (with 10\% FCS): DMEM (16.7 or $25 \mathrm{mmol} / \mathrm{l}$ glucose); CMRL 1066 (5.5 mmol/1 glucose); RPMI 1640 (11 mmol/l glucose); MCDB 104 (4 mmol/l glucose); F12/Ham ( 9 mmol/l glucose). Cell survival and the morphological aspect of the cells (and notably cellular "blebbing" as evidence of imminent cell death due to apoptosis) was observed over 15 days. According to these criteria, the most appropriate medium was seen to be CMRL 1066 (data not shown). This medium was used for all subsequent experiments.

Even when using CMRL medium, the purified beta cells failed to attach well to the plastic dishes and to spread with time in culture. Furthermore, the vast majority of cells died during the 15-day period. Unsorted cell preparations were used as control and established in culture at the same initial cell density. They showed only minimal signs of necrosis or apoptosis. Even without any additional coating of the plastic culture dishes, these cells adhered (data not shown). Under such conditions there was the expected overgrowth of fibroblastoid cells that rapidly filled the dishes.

When purified rat beta cells are seeded in $50 \mu \mathrm{l}$ droplets at high cell density in plastic dishes not treated to promote adherence of mammalian cells (i.e. bacterial dishes), they typically aggregate spontaneously into small clusters. Interestingly enough, when the purified human beta cells were handled in this same way, there was little if any aggregation, suggesting that the panel of cell adhesion molecules needed for intercellular adhesion of human beta cells was missing.
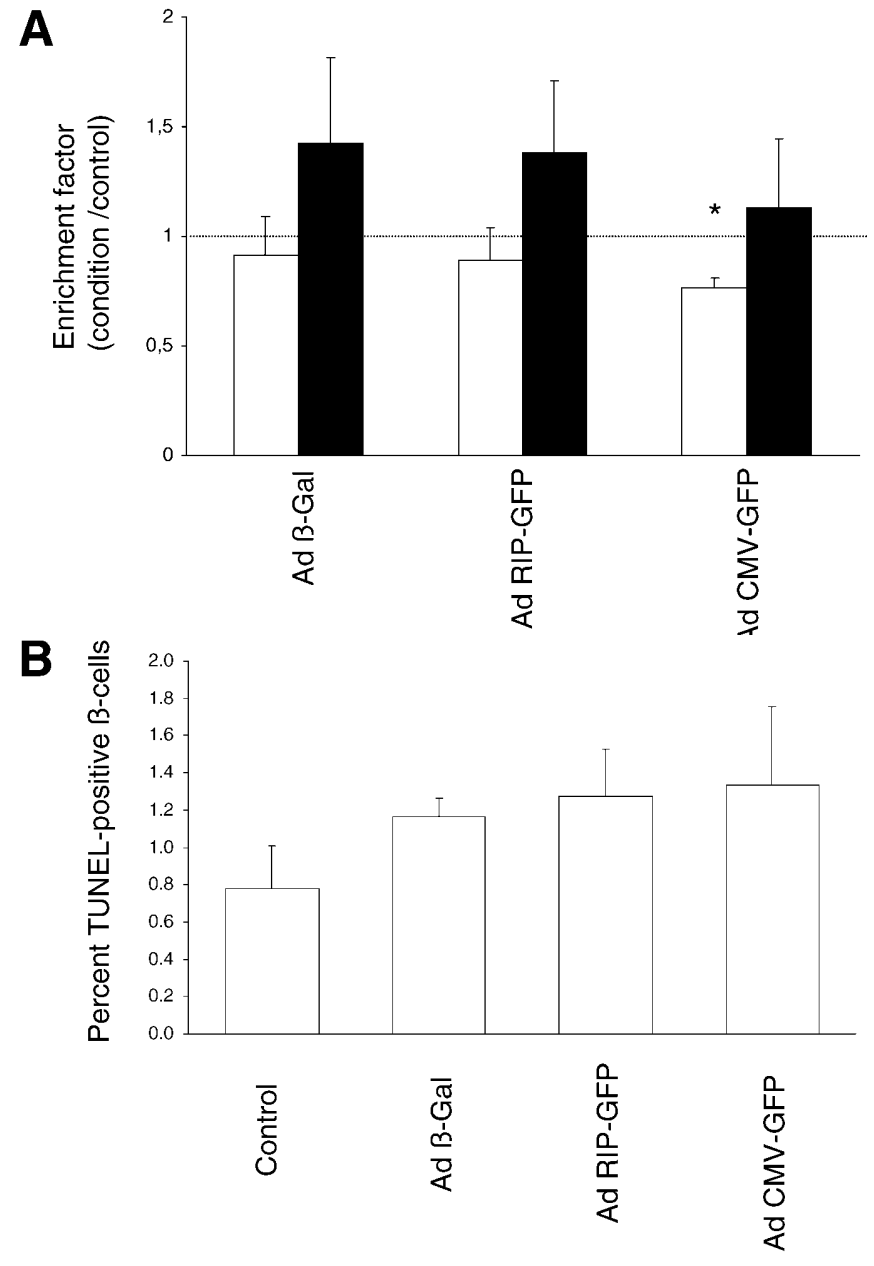

Fig. 1A, B. Effect of GFP expression and adenoviral infection on apoptosis of human beta cells: Human islets were partially dissociated and infected with adenovirus expressing GFP under the control of the insulin promoter (AdRIP-GFP) or the CMV promoter (AdCMV-GFP), by adenovirus expressing $\beta$-galactosidase driven by the CMV promoter (Ad $\beta$-gal) or were not infected (control). They were studied 4 days after infection. A apoptosis (open bars) and necrosis (black bars) measured by ELISA. Data are expressed as the "enrichment factor" for infected cells relative to non-infected cells (normalized to 1) (means $\pm \mathrm{SEM}, n=4$ observations from 2 independent experiments). None of the differences between test and control are statistically significant aside from the small decrease in apoptosis following infection with AdenoCMV-GFP $\left({ }^{*} p<0.05\right)$. B TUNEL combined with immunostaining. Results are expressed as the percentage of insulin-staining cells positive for TUNEL (means $\pm \mathrm{SEM}, n=3$ ). There were no statistically significant differences between groups

Effect of adenovirus infection and expression of GFP on beta-cell apoptosis. The poor survival of the purified cells in culture could have been due to the sorting procedure employed, and most specifically either to infection with adenovirus in itself or to expression of GFP or both. The use of the insulin promoter to drive GFP expression could equally have been detrimental. To test this, dissociated islets were infected with adenovirus expressing GFP under control of the insulin promoter (RIP-GFP) or the CMV promoter (CMV- 
A

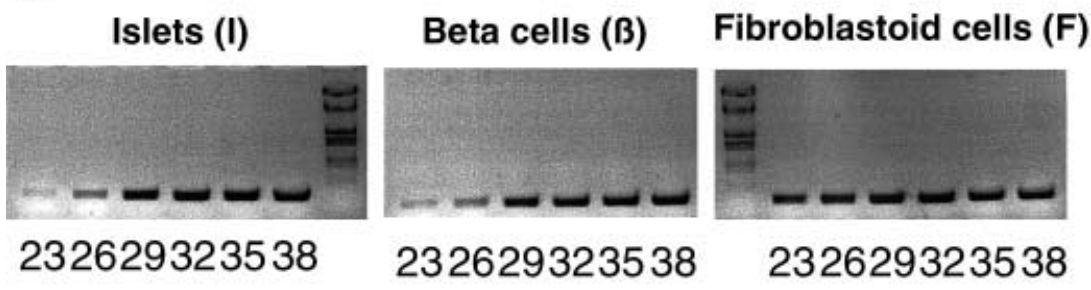

B

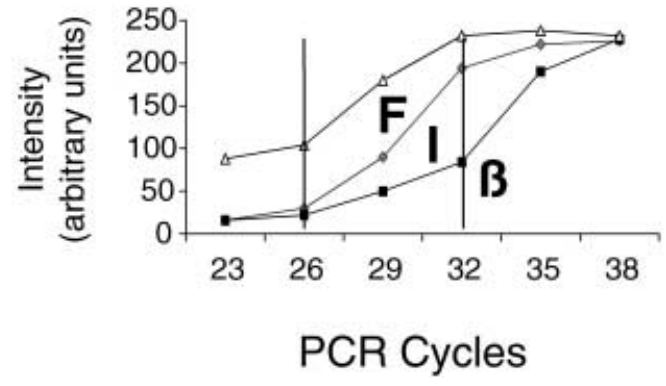

Fig. 2A, B. Semi-quantitative RT-PCR for $\beta 1$ integrin. A mRNA from islets, purified beta cells and fibroblastoid cells was reverse-transcribed and amplified from 23 to 38 PCR cycles. A sample was taken every three cycles. B Band intensities expressed in arbitrary units. Quantitative comparison was possible in the linear range of the curve (between the two vertical lines) for all three cell types

GFP) or expressing $\beta$-galactosidase (CMV- $\beta$ gal). Toxicity was assessed by ELISA (quantification of apoptosis and necrosis), surface binding of annexin $\mathrm{V}$ (a marker for apoptosis from its earliest stages) and TUNEL (to assess DNA fragmentation). The number of annexin positive cells was not increased following infection with any of the three viruses (not shown). Furthermore, there were no significant increases in apoptosis, as measured either by ELISA (Fig. 1A) or TUNEL (Fig. 1B) or necrosis (Fig. 1A). The small but significant reduction in apoptosis observed following expression with the CMV-GFP adenovirus remains enigmatic but is not relevant to this study. It is concluded that the infection with adenovirus and expression of GFP in beta cells are not responsible directly for increased apoptosis in our experimental system.

Expression of integrins by human beta cells. The expression of select integrin subunits was studied using a semi-quantitative RT-PCR in human islets, purified human beta cells and human pancreatic fibroblastoid cells (derived from such cells which had overgrown cultures of human islets). A representative experiment (for $\beta 1$ ) is shown in Fig. 2. In each instance, the bandintensity of the expected fragment was measured with increasing cycle number. For purposes of quantitative comparison between cell types, a cycle number was chosen that was within the linear amplification range for all three cDNA preparations (between 26 and 32

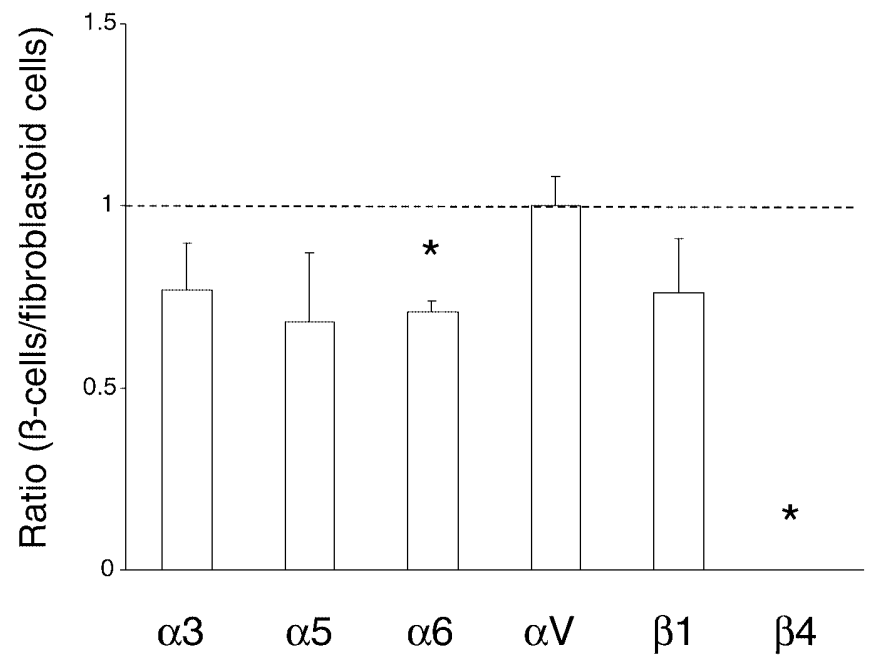

Fig. 3. Expression of select integrins in human beta cells: mRNA levels for the indicated integrins were measured by semi-quantitative RT-PCR. Results are expressed as the ratio in human beta cells to that observed in human pancreatic fibroblastoid cells. (means $\pm \mathrm{SEM}, n=4$ ). ${ }^{*}$ Significantly decreased in beta cells vs fibroblastoid cells $(p<0.01)$. Note that expression of integrin $\beta 4$ was high in the fibroblastoid cells but was not detectable in the beta cells

cycles in Fig. 2). mRNAs for integrin subunits $\alpha 3, \alpha 5$, $\alpha 6, \alpha \mathrm{V}$ and $\beta 1$ were found in the three cell types, whereas $\beta 4$ was detected in the fibroblastoid and islet cells but not in purified beta cells. When the relative expression of each of these subunits was compared between beta cells and fibroblastoid cells (Fig. 3), it was found that $\alpha 3, \alpha 5, \alpha 6$ and $\beta 1$ seemed to be expressed in slightly lower amounts in the purified beta cells. However, only $\alpha 6$ was seen to be significantly decreased $(p<0.05)$.

Integrin $\beta 4$ expression in islets was seen to increase with time in culture (Fig. 4). Given the absence of detectable $\beta 4$ expression in purified beta cells, this in- 


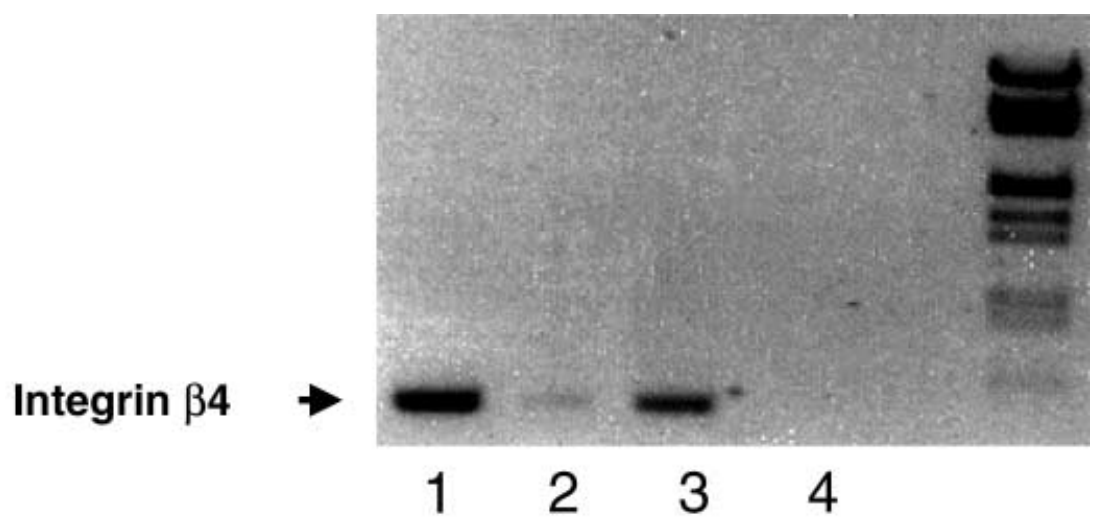

Fig. 4. RT-PCR analysis of integrin $\beta 4$ subunit: The Expression of integrin $\beta 4$ was analysed under four conditions: 1: Pancreatic fibroblastoid cells; 2 : islets after 2 days in culture; 3 : islets after 5 days in culture; 4 : purified beta cells after 5 days in culture. There was strong expression of $\beta 4$ in fibroblastoid cells with no detectable expression in purified beta cells. The increased expression in the islet preparation with time is thus presumed to be related to overgrowth by contaminating fibroblastoid cells

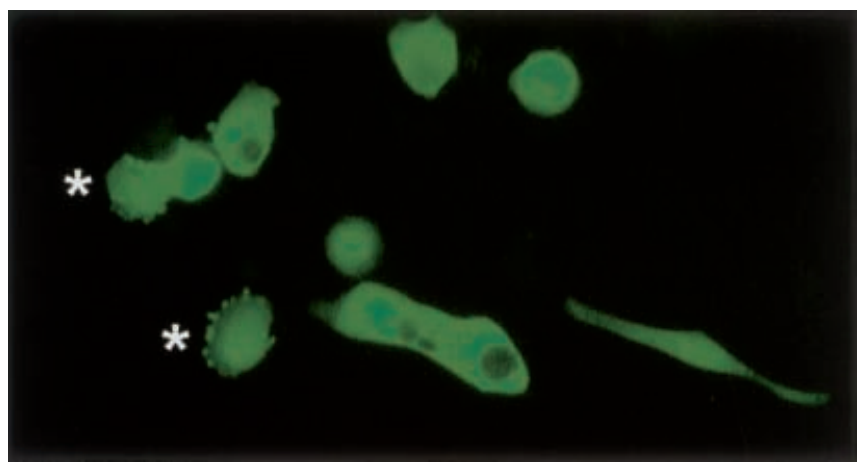

Fig. 5. Fluorescence microscopy of sorted human beta cells expressing GFP 5 days after plating on a lawn of lysed 5637 cells. The cells show varying degrees of spreading while some $($ marked $*$ ) present surface "blebbing" reminiscent of apoptosis

crease is taken to reflect the growth of $\beta 4$-positive fibroblastoid cells that typically contaminate even the purest human islet preparations.

Effect of different matrices on beta-cell spreading and survival. Cells adhere and spread on an extracellular matrix by virtue of binding of cell surface integrins to their cognate proteins in the matrix. The identification of a discrete panel of integrins expressed by purified beta cells thus allowed for matching to their cognate extracellular matrix components with a view to improving cell attachment and spreading, as outlined in Table 1 . Beta cells were seeded in 96 well plates precoated with each of these matrices or matrix proteins and any impact on spreading and survival of purified beta cells documented (Table 1). The only condition that did so was culture on a lawn of lysed human blad-
Table 1. Impact on cell morphology and survival of matching extracellular matrix ligands with cognate integrins expressed by human beta cells

\begin{tabular}{|c|c|c|c|c|}
\hline ECM ligand & $\begin{array}{l}\text { Cognate } \\
\text { integrins }\end{array}$ & Attachment & Spreading & Survival \\
\hline $\begin{array}{l}\text { Lyzed } 5637 \\
\text { cells (Human } \\
\text { laminins) }\end{array}$ & $\alpha_{6} \beta_{1}, \alpha_{3} \beta_{1}$ & Yes & Yes & Yes \\
\hline $\begin{array}{l}\text { Lyzed } 804 \\
\text { G cells } \\
\text { (Rat laminins) }\end{array}$ & $\alpha_{6} \beta_{1}, \alpha_{3} \beta_{1}$ & No & No & No \\
\hline $\begin{array}{l}5637 \text { cells } \\
\text { conditioned } \\
\text { medium } \\
\text { (Human } \\
\text { laminins) }\end{array}$ & $\alpha_{6} \beta_{1}, \alpha_{3} \beta_{1}$ & No & No & No \\
\hline $\begin{array}{l}804 \mathrm{G} \text { cells } \\
\text { conditioned } \\
\text { medium (Rat } \\
\text { laminins) }\end{array}$ & $\alpha_{6} \beta_{1}, \alpha_{3} \beta_{1}$ & No & No & No \\
\hline Fibronectin & $\begin{array}{l}\alpha_{3} \beta_{1}, \alpha_{5} \beta_{1} \\
\alpha_{v} \beta_{3}, \alpha_{v} \beta_{5}\end{array}$ & Yes & No & No \\
\hline Vitronectin & $\alpha_{v} \beta_{3}, \alpha_{v} \beta_{5}$ & Yes & No & No \\
\hline Gelatin & $\begin{array}{l}\alpha_{1} \beta_{1}, \alpha_{3} \beta_{1}, \\
\alpha_{5} \beta_{1}\end{array}$ & Yes & No & No \\
\hline
\end{tabular}

der carcinoma cells (5637 cells), known to deposit a matrix rich in laminins. On this matrix, the cells spread out after $24 \mathrm{~h}$ and survived up to two weeks. Interestingly, such was not the case on a matrix produced by a rat bladder carcinoma cell line $(804 \mathrm{G}$ cells) and shown by us previously to promote the spreading of purified rat beta cells [12]. It remains to be established whether this was due to the different origin of matrix proteins.

Effect of antioxidants and caspase inhibitors on survival of human beta cells in culture. Despite optimisation of the medium and substratum, even the human beta cells plated in CMRL on a lawn of lysed 5637 cells showed marked morphological evidence of apoptosis, and notably cellular blebbing (Fig. 5). Apoptosis was confirmed by fluorescence staining of beta cells using annexin $\mathrm{V}$ labelling. The percentage of annexin $\mathrm{V}$ positive cells increased from $15.3 \pm 8.5 \%$ after 1 day 
in culture, to $61.5 \pm 0.7 \%$ after 10 days (means $\pm \mathrm{SD}$ from two independent experiments). In order to protect the cells from necrosis or apoptosis, anti-apoptotic agents and antioxidants were added to the medium. To try to reduce apoptosis, Z-VAD, a caspase inhibitor, was added to the medium during the first $24 \mathrm{~h}$ of culture in suspension after cell sorting. When quantified by ELISA (for end-stage apoptosis and necrosis), Z-VAD decreased apoptosis by $40 \pm 9 \%$ (mean \pm SEM, $n=4 ; p<0.05)$. There was no apparent difference in annexin $\mathrm{V}$ coloration between the treated and the nontreated condition.

The antioxidants tested were nicotinamide (10 $\mathrm{mmol} / \mathrm{l})$, butylated hydroxyanisole (BHA, $100 \mu \mathrm{mol} / \mathrm{l}$ ) and $\mathrm{N}$-acetyl cysteine (NAC, $1 \mathrm{mmol} / \mathrm{l}$ ). Of these, nicotinamide was the most effective in terms of the total number of viable cells remaining in the dishes after 10 days of culture (based upon counting a mean of 67.3 cells/field (range 28-146) in a total of 5 random fields).

Static insulin secretion from human purified beta cells. Insulin secretion was measured after maintaining the purified beta cells in culture for 1 or 6 days in CMRL medium with $10 \mathrm{mmol} / \mathrm{l}$ nicotinamide, with or without addition of $20 \mu \mathrm{mol} / \mathrm{l} \mathrm{Z}-\mathrm{VAD}$ for the first $24 \mathrm{~h}$ of culture. For measurement of static insulin secretion, cells were first pre-incubated in KRB-Hepes at $2.8 \mathrm{mmol} / 1$ glucose for $30 \mathrm{~min}$ followed by $1 \mathrm{~h}$ at $2.8 \mathrm{mmol} / \mathrm{l}$ glucose (basal) and then a second $1 \mathrm{~h}$ incubation at $16.7 \mathrm{mmol} / \mathrm{l}$ glucose with or without addition of IBMX/forskolin. The concentration of insulin (means $\pm \mathrm{SE}, n=3$ ) at the end of the $1 \mathrm{~h}$ basal period was $784 \pm 365 \mathrm{mU} / \mathrm{L}$ (control) compared with $927 \pm 668 \mathrm{mU} / \mathrm{L}(+\mathrm{ZVAD})$ after 1 day of culture and $507 \pm 412$ compared with $267 \pm 140$ respectively after 6 days. The large errors in these absolute concentrations reflect variability in cell numbers for the 3 independent experiments. In order to compare the regulation of insulin secretion with or without treatment with ZVAD, it was thus necessary to consider the fold-increase in secretion (stimulated vs basal) during the two sequential 1-h incubations. The cells failed to respond to high $(16.7 \mathrm{mmol} / \mathrm{l})$ glucose alone under any of the conditions studied. However, stimulation by $16.7 \mathrm{mmol} / \mathrm{l}$ glucose with elevated cAMP $(0.1 \mathrm{mmol} / \mathrm{l}$ IBMX and $5 \mu \mathrm{mol} / \mathrm{l}$ forskolin) did elicit an increase in insulin secretion. Under these conditions, the foldincrease in secretion 1 day after cell sorting was $1.7 \pm 1.1$ for the control condition and $2.4 \pm 1.0$ for cells treated with the caspase inhibitor (means \pm SEM, $n=3$; n.s.). After 6 days in culture, the fold-increase in insulin secretion was $1.6 \pm 0.5$ for the control and $3.3 \pm 0.2$ for cells treated with Z-VAD for the first day of culture (means SEM, $n=3 ; p<0.05$ ), suggesting that shortterm early exposure to the caspase inhibitor had continuing beneficial effects on cell function after its removal.
Recommended culture conditions for purified human beta cells. On the basis of the above experimental results, we propose the following method for maintaining purified human beta cells in culture. The cells should be cultured in CMRL 1066 medium, with $5.5 \mathrm{mmol} / \mathrm{l}$ glucose and $10 \%$ FCS, with $10 \mathrm{mmol} / \mathrm{l}$ nicotinamide present at all times. After 24-h of droplet culture in suspension to allow for recovery from the sorting procedure, cells are plated at a concentration of 20,000 cells/well in $300 \mu \mathrm{l}$ medium in 96-well plates carrying a lawn of lyzed 5637 cells. To decrease apoptosis and improve cell function, Z-VAD is added for the first $24 \mathrm{~h}$ at a concentration of $20 \mu \mathrm{mol} / \mathrm{l}$.

It is important to note that although these conditions do favour survival of sorted beta cells in culture over a 15-day period of study, a large number of cells still die with time, in keeping with the observation that apoptosis was reduced but not absent.

\section{Discussion}

Multiple approaches have been described to purify islet beta cells. The most common is based on cell sorting according to the autofluorescence of rat beta cells $[23,24]$. Although most useful for the sorting of rat beta cells, this approach has not proved adequate for the effective purification of human beta cells and attempts to refine the method for this purpose [25] only resulted in a cell-population of 70-85\% purity. Other methods have not proved any better [26]. More recently, using an adenoviral vector for beta-cell specific expression of GFP, a population of human beta cells of $95 \%$ purity was obtained [10]. This approach has opened the way to detailed studies on human beta cells without the results being confounded by the presence of islet non-beta cells. We have now applied the approach to the study of the survival of such cells in culture. We consider this an essential preliminary step towards the development of any stratagem for cellreplacement therapy of Type I (insulin-dependent) diabetes mellitus, by which insulin-producing cells, and by choice fully differentiated beta cells regardless of their derivation, will have to be maintained in culture before their implantation in patients.

It has been suggested by others that GFP is itself intrinsically toxic towards rat beta cells and other cell types [27, 28]. In this study, there was no evidence of increased apoptosis or necrosis of cells expressing GFP, regardless of whether expression was driven by the insulin or CMV promoter. Adenovirus expressing an unrelated protein ( $\beta$-galactosidase) was also not seen to be toxic. It is thus concluded that in the present experimental setting, sorting human beta cells on the basis of GFP fluorescence is valid. The reason for others observing GFP-toxicity remains unclear. Differences between rat and human cells could be one explanation as could be differences in both experimental 
protocols and methods of analysis. Nonetheless, we are left to conclude that the poor survival of human beta cells once they have been sorted is not due to GFP.

It was immediately apparent that the purified human beta cells were peculiarly fragile in standard culture conditions. The morphological and biochemical evidence for apoptosis indicated that this was due in large part to activation of programmed cell-death pathway(s). The major focus of the study was thus an attempt to limit such activation by optimisation of the culture conditions with particular emphasis on the culture medium, ECM and inhibition of caspases.

The choice of culture medium has been shown to be important for the maintenance of insulin secretion in cultured islets from a variety of species, with CMRL 1066 being the best for human islets [29]. Because it was not apparent a priori that purified human beta cells would have the same demands as intact islets in this regard, a number of culture media were tested. We now confirm that CMRL 1066 is the best for these purified cells as well. Note that even when maintained in culture with this medium, and as discussed below, unlike intact human islets, the purified cells failed to display stimulated insulin secretion in response to glucose alone.

The role of integrins has been reported as crucial for maintenance of beta-cell viability and differentiation [13, 18, 30, 31, 32]. Studies from our own group have further demonstrated the specific role of integrins $\alpha 3 \beta 1$ and $\alpha 6 \beta 1$ on rat beta cells $[12,33$ ]. Disruption of inter-islet cell contacts and purification of beta cells away from other cell types possibly contributing to the deposition of ECM components in islet cultures was considered to be a confounding factor in allowing the purified cells to thrive in culture. Until now, there has been no clear information regarding integrin expression on human islet cells aside from indirect data obtained from immunocytochemistry on isolated islets $[17,34]$ or the developing human pancreas [34]. In both instances, limiting resolution and sensitivity of immunocytochemistry made it difficult to ascertain which integrins were truly expressed by beta cells. We have now taken advantage of our access to purified human beta cells in order to identify some of the more important integrin subunits expressed by these cells. Given the small numbers of cells available and the fact that commercially available antibodies were not found to be reliable for quantitative evaluation of integrin expression on isolated cells (Ris et al, unpublished observation), we used semi-quantitative RT-PCR for this purpose. Based on previous work on rat beta cells [12] specific attention was paid to integrins $\alpha 3, \alpha 5, \alpha 6, \alpha \mathrm{V}, \beta 1$ as well as $\beta 4$. The data show unequivocal expression of mRNA for integrins $\alpha 3$, $\alpha 5, \alpha 6, \alpha \mathrm{V}$ and $\beta 1$ but not $\beta 4$ in human beta cells. Expression of these integrins appears to be similar to that seen in fibroblasts derived from human islet prep- arations left in culture for prolonged periods. Strikingly, the $\beta 4$ integrin subunit is not expressed in human beta cells but is so in the fibroblasts. As a consequence of such differential expression, combined with the rapid outgrowth over just a few days of fibroblasts, which inevitably contaminate all islet preparations, the expression of $\beta 4$ in whole islet preparations increases with time in culture. We cannot, however, exclude that fibroblasts could in addition promote the expression of $\beta 4$ on beta cells themselves. IntegrinECM interactions can be predicted on the basis of the known binding characteristics of the integrin superfamily [35]. Initial attempts to promote human betacell attachment and spreading by coating dishes with purified proteins known to be cognate ligands for the integrins expressed in these cells (and notably fibronectin, vitronectin and gelatin) were unsuccessful. This suggested that a more complex array of ECM proteins would be needed for this purpose. Given our previous demonstration of excellent attachment and spreading of rat beta cells to ECM secreted by $804 \mathrm{G}$ (rat bladder carcinoma) cells [12], we were surprised to discover that this particular ECM that is enriched in laminin 5 [36] failed to promote attachment and spreading of the human beta cells. Others have claimed that $804 \mathrm{G}$ matrix promotes proliferation of adult human islet cells [37] but the proliferating cell type was subsequently shown by another group to be ductal rather than endocrine [38]. The absence of nonbeta cells and their contribution to beta-cell survival in culture (possibly including deposition of ECM components which could compliment $804 \mathrm{G}$ components), could make the $804 \mathrm{G}$ matrix inappropriate for the purified human beta-cell preparation. Others had shown that the human counterpart of $804 \mathrm{G}$ cells, the human bladder carcinoma line 5637, was useful for formation of monolayers from intact human islets [39, 40]. It was found that the human beta cells did indeed attach and spread better on a lawn of lysed 5637 cells than on any other ECM tested, in keeping with the deposition by 5637 cells of laminins which should be bound by both $\alpha 3 \beta 1$ and $\alpha 6 \beta 1$ expressed on the beta cells. Conditioned medium from 5637 cells was not found adequate for this purpose.

Even with improved attachment and spreading of purified human beta cells to lysed 5637 cell-lawns, the survival of the cells was not much improved. There were signs of both necrosis and apoptosis. In order to limit oxidative stress, a known cause of necrosis, antioxidants were added to the culture medium. Only nicotinamide showed a beneficial effect on beta cell survival and after this initial observation, it was included systematically. In keeping with this observation, nicotinamide has been shown by others to maintain beta-cell differentiation [41], enhance transcription of islet-specific genes [32] and inhibit poly (ADP-ribose) polymerase (PARP) involved in cell death [42]. There was still, however, morphological 
evidence for cell distress and widespread apoptosis after just a few days in culture, and this was born out by specific evidence for early and late apoptotic events. Others have shown that fetal islet cells suffer when cell-ECM contacts are disturbed [14]. It is thus entirely possible that 5637 cells provide only partial restoration of integrin signalling to the purified beta cells. These same authors showed the beneficial effects of including a caspase inhibitor (Z-VAD or FK009) in the culture medium. We confirm their finding, with Z-VAD decreasing apoptosis by $40 \%$.

The results of this study are encouraging but by no means definitive. Survival of human beta cells in culture is certainly improved by following the protocol presented here and it is felt that this in itself is of value to the scientific community. Our results stress again the inherent difficulties encountered with working with human cells and the dramatic differences between rat and human beta cells. The latter survive well in culture even after purification by cell sorting and display a decent insulin secretory response to glucose $[12,23]$. The human cells continued to die over time in culture even if this was reduced using the present, new protocol. Furthermore, insulin secretion could not be stimulated from these cells with glucose alone, but only in combination with higher cAMP. Even then, the fold-stimulation was modest compared with intact human islets. Clearly, other factors are playing a role. These could include noxious products of the beta cells themselves [43] or lack of positive/protective factors normally contributed by the non-beta cells of human isolated islets. These must now be addressed in further studies and appropriate intervention conceived to block entirely cell death and restore glucose-sensitivity. Targeted intervention in apoptotic and/or oxidative stress and inflammatory signalling pathways could be one such approach. Such methodology will also be essential, in our opinion, for obtaining the large numbers of highly differentiated insulin-secreting cells envisaged for cell replacement therapy [44] regardless of whether they have been derived by conditional immortalisation of beta cells $[4,5]$, from adult [6] or embryonal $[7,8,9]$ stem cells or by any other means for creating surrogate beta cells.

Acknowledgements. This work was supported by the Juvenile Diabetes Foundation International (Nos. 4-1999-844 to P.A. Halban and P. Morel and 1-2000-692 to D. Rouiller), by the Swiss National Science Foundation (Nos. 3200-061776.00 to P.A. Halban and 32-0618703 to P. Morel and J. Oberholzer) and by the Geneva Diabetes Foundation (to P. Morel and J. Oberholzer).

\section{References}

1. Oberholzer J, Triponez F, Mage R et al. (2000) Human islet transplantation: lessons from 13 autologous and 13 allogeneic transplantations. Transplantation 69:1115-1123
2. Shapiro AMJ, Lakey JRT, Ryan EA et al. (2000) Islet transplantation in seven patients with type 1 diabetes mellitus using a glucocorticoid-free immunosuppressive regimen. N Engl Med 343:230-238

3. Weir GC, Bonner-Weir S (1997) Scientific and political impediments to successful islet transplantation. Diabetes 46:1247-1256

4. Dufayet De La Tour D, Halvorsen T, Demeterco C et al. (2001) beta-Cell Differentiation from a Human Pancreatic Cell Line in Vitro and in Vivo. Mol Endocrinol 15:476-483

5. Salmon P, Oberholzer J, Occhiodoro T, Morel P, Lou J, Trono D (2000) Reversible immortalization of human primary cells by lentivector- mediated transfer of specific genes. Mol Ther 2:404-414

6. Bonner-Weir S, Taneja M, Weir GC et al. (2000) In vitro cultivation of human islets from expanded ductal tissue. Proc Nat Acad Sci USA 97:7999-8004

7. Assady S, Maor G, Amit M, Itskovitz-Eldor J, Skorecki KL, Tzukerman M (2001) Insulin production by human embryonic stem cells. Diabetes 50:1691-1697

8. Lumelsky N, Blondel O, Laeng P, Velasco I, Ravin R, McKay R (2001) Differentiation of embryonic stem cells to insulin-secreting structures similar to pancreatic islets. Science 292:1389-1394

9. Soria B, Roche E, Berna G, Leon-Quinto T, Reig JA, Martin F (2000) Insulin-secreting cells derived from embryonic stem cells normalize glycemia in streptozotocininduced diabetic mice. Diabetes 49:157-162

10. Meyer K, Irminger JC, Moss LG et al. (1998) Sorting human beta-cells consequent to targeted expression of green fluorescent protein. Diabetes 47:1974-1977

11. Ricordi C, Finke EH, Dye ES, Socci C, Lacy PE (1988) Automated isolation of mouse pancreatic islets. Transplantation 46:455-457

12. Bosco D, Meda P, Halban PA, Rouiller DG (2000) Importance of cell-matrix interactions in rat islet beta-cell secretion in vitro: role of alpha6beta1 integrin. Diabetes 49:233-243

13. Lucas-Clerc C, Massart C, Campion JP, Launois B, Nicol M (1993) Long-term culture of human pancreatic islets in an extracellular matrix: morphological and metabolic effects. Mol Cell Endocrinol 94:9-20

14. Beattie GM, Leibowitz G, Lopez AD, Levine F, Hayek A (2000) Protection from cell death in cultured human fetal pancreatic cells. Cell Transplant 9:431-438

15. Farrelly N, Lee YJ, Oliver J, Dive C, Streuli CH (1999) Extracellular matrix regulates apoptosis in mammary epithelium through a control on insulin signaling. J Cell Biol 144:1337-1348

16. Rosenberg L, Wang R, Paraskevas S, Maysinger D (1999) Structural and functional changes resulting from islet isolation lead to islet cell death. Surgery 126:393-398

17. Wang RN, Rosenberg L (1999) Maintenance of beta-cell function and survival following islet isolation requires reestablishment of the islet-matrix relationship. J Endocrinol 163:181-190

18. Wang RN, Paraskevas S, Rosenberg L (1999) Characterization of integrin expression in islets isolated from hamster, canine, porcine, and human pancreas. J Histochem Cytochem 47:499-506

19. Ricordi C, Lacy PE, Finke EH, Olack BJ, Scharp DW (1988) Automated method for isolation of human pancreatic islets. Diabetes 37:413-420

20. Brocco MA, Panzetta P (1999) Survival and process regrowth of purified chick retinal ganglion cells cultured in a growth factor lacking medium at low density. Modulation by extracellular matrix proteins. Brain Res Dev Brain Res 118:23-32 
21. Huppertz B, Frank HG, Kaufmann P (1999) The apoptosis cascade - morphological and immunohistochemical methods for its visualization. Anat Embryol (Berl) 200:1-18

22. Cattan P, Berney T, Schena S et al. (2001) Early assessment of apoptosis in isolated islets of Langerhans. Transplantation 71:857-862

23. Pipeleers DG, in't Veld PA, Van de Winkel M, Maes E, Schuit FC, Gepts W (1985) A new in vitro model for the study of pancreatic A and B cells. Endocrinology 117:806816

24. Van de Winkle M, Maes E, Pipeleers D (1982) Islet cell analysis and purification by light scatter and autofluorescence. Biochem Biophys Res Commun 107:525-532

25. Ling Z, Pipeleers DG (1996) Prolonged exposure of human beta cells to elevated glucose levels results in sustained cellular activation leading to a loss of glucose regulation. J Clin Invest 98:2805-2812

26. Lukowiak B, Vandewalle B, Riachy R et al. (2001) Identification and purification of functional human beta-cells by a new specific zinc-fluorescent probe. J Histochem Cytochem 49:519-528

27. Heimberg H, Heremans Y, Jobin C et al. (2001) Inhibition of cytokine-induced NF-kappaB activation by adenovirusmediated expression of a NF-kappaB super-repressor prevents beta-cell apoptosis. Diabetes 50:2219-2224

28. Liu HS, Jan MS, Chou CK, Chen PH, Ke NJ (1999) Is green fluorescent protein toxic to the living cells? Biochem Biophys Res Commun 260:712-717

29. Holmes MA, Clayton HA, Chadwick DR, Bell PR, London NJ, James RF (1995) Functional studies of rat, porcine, and human pancreatic islets cultured in ten commercially available media. Transplantation 60:854-860

30. Aharoni D, Meiri I, Atzmon R, Vlodavsky I, Amsterdam A (1997) Differential effect of components of the extracellular matrix on differentiation and apoptosis. Curr Biol 7:43-51

31. Beattie GM, Lappi DA, Baird A, Hayek A (1991) Functional impact of attachment and purification in the short term culture of human pancreatic islets. J Clin Endocrinol Metab 73:93-98

32. Beattie GM, Rubin JS, Mally MI, Otonkoski T, Hayek A (1996) Regulation of proliferation and differentiation of human fetal pancreatic islet cells by extracellular matrix, hepatocyte growth factor, and cell-cell contact. Diabetes 45:1223-1228
33. Kantengwa S, Baetens D, Sadoul K, Buck CA, Halban PA, Rouiller DG (1997) Identification and characterization of alpha 3 beta 1 integrin on primary and transformed rat islet cells. Exp Cell Res 237:394-402

34. Cirulli V, Beattie GM, Klier G et al. (2000) Expression and function of alpha(v)beta(3) and alpha(v)beta(5) integrins in the developing pancreas: roles in the adhesion and migration of putative endocrine progenitor cells. J Cell Biol 150:1445-1460

35. Sugimori T, Griffith DL, Arnaout MA (1997) Emerging paradigms of integrin ligand binding and activation. Kidney Int 51:1454-1462

36. Langhofer M, Hopkinson SB, Jones JC (1993) The matrix secreted by $804 \mathrm{G}$ cells contains laminin-related components that participate in hemidesmosome assembly in vitro. J Cell Sci 105:753-764

37. Hayek A, Beattie GM, Cirulli V, Lopez AD, Ricordi C, Rubin JS (1995) Growth factor/matrix-induced proliferation of human adult beta-cells. Diabetes 44:1458-1460

38. Lefebvre VH, Otonkoski T, Ustinov J, Huotari MA, Pipeleers DG, Bouwens L (1998) Culture of adult human islet preparations with hepatocyte growth factor and $804 \mathrm{G}$ matrix is mitogenic for duct cells but not for beta-cells. Diabetes 47:134-137

39. Beattie GM, Cirulli V, Lopez AD, Hayek A (1997) Ex vivo expansion of human pancreatic endocrine cells. J Clin Endocrinol Metab 82:1852-1856

40. Quentmeier H, Zaborski M, Drexler HG (1997) The human bladder carcinoma cell line 5637 constitutively secretes functional cytokines. Leuk Res 21:343-350

41. Soria B, Andreu E, Berna G et al. (2000) Engineering pancreatic islets. Pflugers Arch 440:1-18

42. Revoltella RP, Borney F, Dal Canto B, D’Urso CM (1993) Apoptosis of serum-free C2.8 mouse embryo hepatocytic cells caused by hepatocyte growth factor deprivation. Cytotechnology 13:13-19

43. Pipeleers D, Hoorens A, Marichal-Pipeleers M, Van de Casteele M, Bouwens L, Ling Z (2001) Role of pancreatic beta-cells in the process of beta-cell death. Diabetes 50 [Suppl 1]:S52-S57

44. Halban PA, Kahn SE, Lernmark A, Rhodes CJ (2001) Gene and cell-replacement therapy in the treatment of type 1 diabetes: how high must the standards be set? Diabetes 50:2181-2191 